GMR

\title{
Farmer variety exchange along Amazonian rivers influences the genetic structure of manioc maintained in a regional Brazilian GeneBank
}

\author{
S.B. Sousa ${ }^{1}$, G.F. Silva ${ }^{2}$, M.C. Dias ${ }^{2}$, C.R. Clement ${ }^{1}$ and N.R. Sousa ${ }^{2,3}$ \\ ${ }^{1}$ Programa de Pós-Graduação em Genética, Conservação e Biologia Evolutiva, \\ Instituto Nacional de Pesquisas da Amazônia, Manaus, AM, Brasil \\ ${ }^{2}$ Embrapa Amazônia Ocidental, Manaus, AM, Brasil \\ ${ }^{3}$ Embrapa Cocais, São Luís, MA, Brasil \\ Corresponding author: N.R. Sousa \\ E-mail: nelcimar.sousa@embrapa.br
}

Genet. Mol. Res. 16 (3): gmr16039690

Received April 4, 2017

Accepted July 3, 2017

Published July 28, 2017

DOI http://dx.doi.org/10.4238/gmr16039690

Copyright $(2017$ The Authors. This is an open-access article distributed under the terms of the Creative Commons Attribution ShareAlike (CC BY-SA) 4.0 License.

\begin{abstract}
Knowledge of agro-morphological and genetic variability of germplasm diversity is a prerequisite for its use in breeding. The aim of this study was to characterize the genetic diversity of the manioc (Manihot esculenta) Active Germplasm Bank (AGB) at Embrapa Amazônia Ocidental using microsatellite markers. We evaluated 470 accessions collected along five of the main rivers of the Amazon basin: Solimões, Purus, Madeira, Negro, and Amazon. The ten SSR loci used showed high levels of genetic diversity, the polymorphism information content ranged from 0.35 to 0.84 , and the mean number of alleles per locus was 11.3. Accessions from the Madeira River had a higher Shannon index (1.52), as well as the largest number of private alleles (19). Bayesian inference of genetic structure implemented in the Structure software suggested the existence of two groups of accessions without clear association with river basins. The accumulated variation in the first two axes of the principal coordinate analysis revealed low genetic divergence between these groups, while AMOVA identified
\end{abstract}

Genetics and Molecular Research 16 (3): gmr16039690 
most of the molecular variance within the groups. Farmer exchange of varieties along and among rivers probably explains the lack of structure. Although the manioc AGB of Embrapa Amazônia Ocidental contains abundant genetic diversity, no differentiation was found between the groups studied.

Key words: Germplasm; Genetic diversity; Microsatellites; Bitter and sweet manioc

\section{INTRODUCTION}

Manioc (Manihot esculenta Crantz) is currently the fifth most important food crop in the world, consumed primarily in tropical regions, and is the major staple food for more than 800 million people (Lebot, 2009; FAO, 2012). In the most recent FAO statistics, Brazil is the fifth largest producer of manioc in the world (FAOSTAT, 2014). The northern region of Brazil ranks first in production, and manioc culture is one of the main sources of regional farmer income (IBGE - Instituto Brasileiro de Geografia e Estatística, 2015). Most manioc production is processed in the form of commercial flour and starch, while the rest is consumed as homemade foods, such as cooked roots and tucupi.

The domestication of manioc started in southwestern Amazonia, and divergent selection pressures led to two groups of varieties: sweet and bitter (Olsen and Schaal, 2001; Schaal et al., 2006; Mühlen et al., 2013). In Brazil, these varieties are known as macaxeira, aipim, sweet manioc, bitter manioc, industrial manioc, or simply manioc. The groups are not phenotypically differentiated but differ in the levels of cyanogenic glycosides produced in fresh roots. Those with less than $100 \mathrm{mg} / \mathrm{kg}$ are considered sweet varieties, while those with more than $100 \mathrm{mg} / \mathrm{kg}$ are classified as bitter varieties (McKey et al., 2010).

The traditional agriculture practiced by family farmers maintains or increases genetic diversity through the cultivation of different varieties (Ferguson et al., 2012), as well as the occasional incorporation of seedlings (Duputié et al., 2009), and informal exchange of cuttings among farmers (Emperaire and Peroni, 2007). These practices may contribute to the creation of population genetic structure due to different preferences in different regions, and seedling incorporation and exchange can reduce structure.

Embrapa created regional germplasm banks to conserve and support the use of the genetic diversity of manioc in breeding programs, always based initially on local varieties. The evaluation of agro-morphological and genetic diversity of these accessions is important to understand the extent of genetic variability, which is a prerequisite for plant breeding. Genetic diversity is analyzed in germplasm collections, both to complement morpho-agronomic characterization and to answer questions about the genetic relationships among accessions (Sousa et al., 2009). Oliveira-Silva et al. (2014) developed inter-retrotransposon-amplified polymorphism markers for manioc and indicated that these markers were efficient in estimating the genetic diversity of three samples from Amazonas State. They also concluded that these markers were informative for variety discrimination in manioc. However, simple sequence repeats (SSRs) have the additional advantage of being a very informative codominant marker for genetic population analyses (Kalia et al., 2011), and have been used in numerous studies of genetic diversity and structure in Brazilian manioc varieties (Alves-Pereira et al., 2011; Siqueira et al., 2011; Mühlen et al., 2013; Costa et al., 2013). Advances in genotyping with microsatellites

Genetics and Molecular Research 16 (3): gmr16039690 
or SSRs have facilitated the quantification of genetic diversity and the identification of genotypes with specific loci in many GenBanks (Aiemnaka et al., 2012; Paiva, 2013).

The aim of this study was to characterize the genetic diversity of the Manioc Active Germplasm Bank (AGB) at Embrapa Amazônia Ocidental using microsatellite markers to assess the genetic diversity and structure of accessions among and within the main river basins of Brazilian Amazonia, primarily in the State of Amazonas.

\section{MATERIAL AND METHODS}

\section{Plant material}

Four hundred and seventy manioc accessions from the AGB of Embrapa Amazônia Ocidental were evaluated. Passport data that could help to identify patterns in the genetic structure analysis were used to categorize the accessions: 382 accessions from 38 locations were identified in five river basins: Solimões, Purus, Madeira, Negro, and Amazon Rivers (Figure 1). It is worth mentioning that one of the locations (Santa Izabel do Rio Negro) belongs to the Marauiá River, one of the tributaries of the Negro River right bank, and therefore, it was allocated in the Negro River basin. The 88 remaining accessions, introduced from other locations, were not attributed to river basins. In the AGB, 188 accessions have passport information that permits their classification as bitter manioc (111) and sweet manioc (77) varieties.

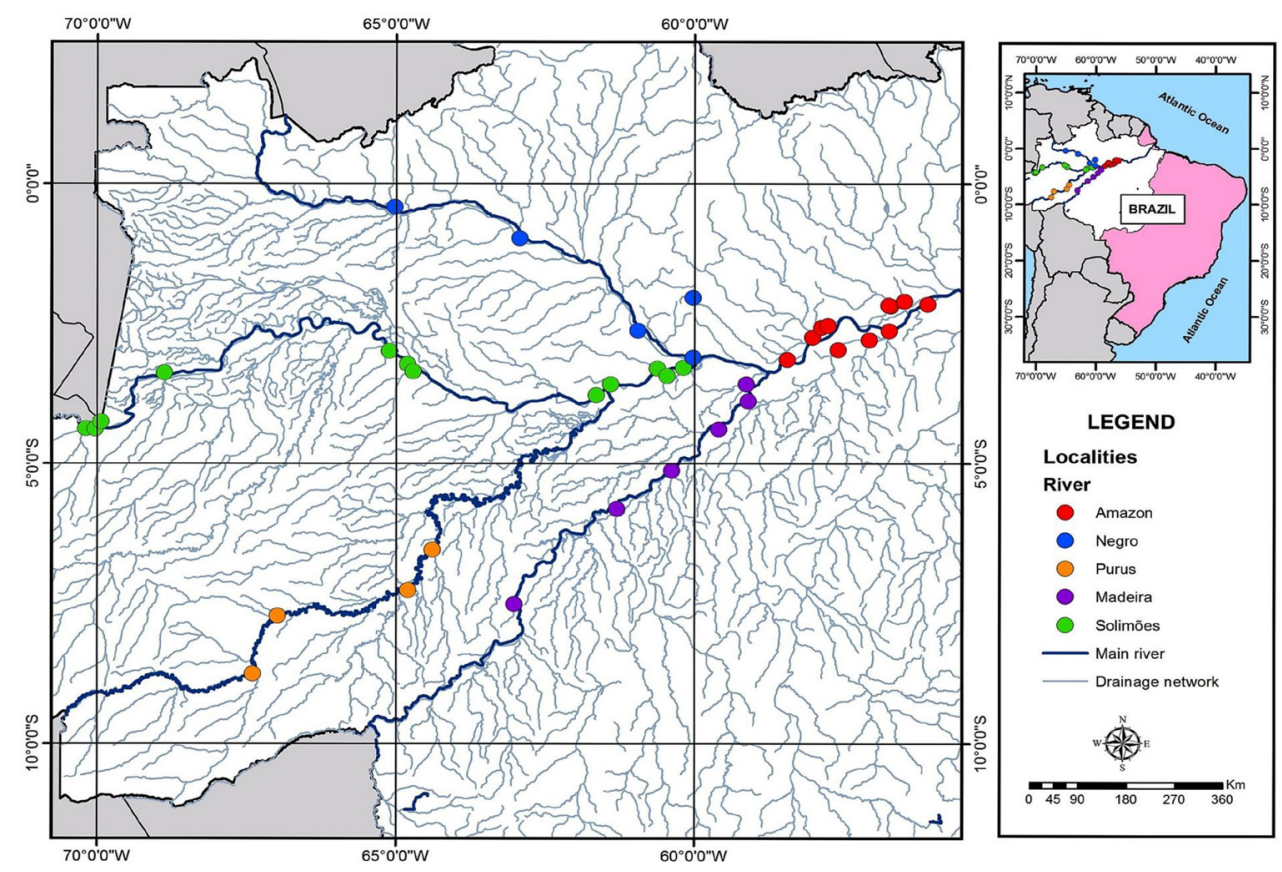

Figure 1. Map with the 38 locations in the Brazilian Amazon basin that supplied accessions to the manioc Active Germplasm Bank at Embrapa Amazônia Ocidental.

Genetics and Molecular Research 16 (3): gmr16039690 


\section{DNA extraction}

Genomic DNA was extracted using the cationic detergent CTAB 2\% protocol (Doyle and Doyle, 1987) in the Molecular Biology Laboratory at Embrapa Amazônia Ocidental. The DNA was quantified by spectrophotometry NanoDrop 1000 (Thermo Scientific) and $0.8 \%$ agarose gel electrophoresis to verify concentration and purity.

\section{SSR genotyping}

Ten microsatellite loci were used: GAGG5, GA12, GA126, GA131, GA134, GA136, GA140 were designed and described by Chavarriaga-Aguirre et al. (1998), and SSRY13, SSRY89, and SSRY164 by Mba et al. (2001) (Table 1). Amplification reactions were carried out with a final volume of $15 \mu \mathrm{L}$, containing $0.4 \mathrm{mM}$ dNTPs, $0.2-0.3 \mu \mathrm{M}$ of each primer, $1 \mathrm{X}$ buffer $\left[500 \mathrm{mM} \mathrm{KCl}, 100 \mathrm{mM}\right.$ Tris- $\mathrm{HCl}\left(\mathrm{pH} 9.0\right.$ at $\left.25^{\circ} \mathrm{C}\right), 15 \mathrm{mM} \mathrm{MgCl}$, $1 \%$ Triton X-100], 1 U Taq DNA polymerase (GenScript), and 50 ng DNA. Amplification was performed in a Veriti thermocycler (Applied Biosystems) with an initial denaturation at $94^{\circ} \mathrm{C}$ for $3 \mathrm{~min}$ followed by 40 cycles of $94^{\circ} \mathrm{C}$ for $30 \mathrm{~s}, 58^{\circ}-61^{\circ} \mathrm{C}$ for $30 \mathrm{~s}$ (depending upon annealing temperature of the primers), $72^{\circ} \mathrm{C}$ for $30 \mathrm{~s}$ and a final extension at $72^{\circ} \mathrm{C}$ for $30 \mathrm{~min}$. The quality of the fragments was verified on $2 \%$ agarose gel. Each forward primer was fluorescently labeled with FAM, allowing analysis by capillary electrophoresis in a Genetic Analyser 3500 (Applied Biosystems) using GeneScan ${ }^{\mathrm{TM}} 600$ LIZ as an internal marker to infer the size of the alleles, and the data were analyzed using the GeneMapper $v$. 4.1 software (Applied Biosystems).

\section{Data analysis}

The genetic diversity parameters (Nei, 1987), the number of alleles and observed and expected heterozygosities, were estimated using ARLEQUIN v. 3.5 (Excoffier and Lischer, 2010). The polymorphism information content (PIC) was calculated with Cervus v. 3.0 (Kalinowski et al., 2007), while the fixation and Shannon indexes were estimated using GenAlex 6.5 (Peakall and Smouse, 2012).

The genetic structure of plant accessions was evaluated by dispersion analysis and clustering of accessions. Principal coordinate analysis ( $\mathrm{PCoA})$ is a method for exploring and visualizing data similarities or dissimilarities and was performed using GenAlex 6.5 (Peakall and Smouse, 2012). The Structure software v. 2.3.1 (Pritchard et al., 2000) was used for Bayesian inferences of the number of clusters that best fits the genotypes based on the $\Delta K$ values described by Evanno et al. (2005). For every K number of clusters, with $\mathrm{K}$ ranging from 1 to 10,20 repetitions were run with no prior population information, considering the model with correlated allele frequencies (admixture model), with 100,000 Markov Chain Monte Carlo iterations and a burn-in period with 200,000 iterations.

Analysis of molecular variance (AMOVA) was performed as described by Excoffier et al. (1992) in the GenAlex 6.5 software package (Peakall and Smouse, 2012) to estimate the genetic differentiation among the groups. The dendrogram of Nei et al. (1983)'s genetic distances among the 470 accessions, calculated in Populations v.1.2.32 (Langella, 1999), was generated in MEGA v.6 (Tamura et al., 2013) using the neighborjoining algorithm.

Genetics and Molecular Research 16 (3): gmr16039690 


\section{RESULTS}

\section{SSR markers}

One hundred and thirteen alleles were detected in the 470 accessions of the Manioc AGB with the 10 SSR loci used, with an average of 11.3 per locus, and a minimum of four and a maximum of 21 alleles per locus (Table 1). The overall genetic diversity as measured by the observed and expected heterozygosity was high in all loci, except for SSRY89. The PIC ranged from 0.35 to 0.84 , with low values for GA134, SSRY89, and GAGG5, indicating that most markers are very informative.

Table 1. Characteristics of the 10 SSR loci analyzed in 470 AGB accessions, including annealing temperature (Ta), allele size range in base pairs $(\mathrm{Ar})$, the number of alleles per locus $\left(N_{\mathrm{A}}\right)$, observed heterozygosity $\left(H_{\mathrm{O}}\right)$, expected heterozygosity $\left(H_{\mathrm{E}}\right)$, and polymorphism information content (PIC).

\begin{tabular}{|c|c|c|c|c|c|c|}
\hline Locus & $\mathrm{Ta}$ & $\operatorname{Ar}(\mathrm{bp})$ & $N_{\mathrm{A}}$ & $H_{\mathrm{O}}$ & $H_{\mathrm{E}}$ & PIC \\
\hline GAGG5 $^{1}$ & $60^{\circ}$ & 114-123 & 6 & 0.523 & 0.509 & 0.438 \\
\hline GA121 & $59^{\circ}$ & 131-142 & 9 & 0.579 & 0.790 & 0.764 \\
\hline GA126 $^{1}$ & $60^{\circ}$ & 176-214 & 14 & 0.745 & 0.829 & 0.816 \\
\hline $\mathrm{GA}^{2} 31^{1}$ & $59^{\circ}$ & $92-123$ & 21 & 0.781 & 0.860 & 0.848 \\
\hline GA134 $^{1}$ & $58^{\circ}$ & $307-325$ & 4 & 0.397 & 0.414 & 0.355 \\
\hline $\mathrm{GA} 136^{1}$ & $59^{\circ}$ & 139-153 & 10 & 0.600 & 0.689 & 0.653 \\
\hline GA140 $^{1}$ & $58^{\circ}$ & 146-169 & 9 & 0.723 & 0.781 & 0.748 \\
\hline${\text { SSRY } 13^{2}}^{2}$ & $58^{\circ}$ & $192-236$ & 20 & 0.455 & 0.844 & 0.835 \\
\hline SSRY89 $^{2}$ & $58^{\circ}$ & $98-118$ & 5 & 0.175 & 0.426 & 0.385 \\
\hline SSRY164² & $60^{\circ}$ & 152-184 & 15 & 0.480 & 0.681 & 0.680 \\
\hline Mean & & & 11.3 & 0.546 & 0.682 & 0.652 \\
\hline
\end{tabular}

${ }^{1}$ Primers developed by Chavarriaga-Aguirre et al. (1998); ${ }^{2}$ Primers developed by Mba et al. (2001).

\section{Genetic diversity and structure analysis}

The Bayesian simulations identified two groups $(K=2)$. Neither group had a predominance of bitter or sweet varieties, although group I $(\mathrm{N}=135)$ had 29 bitter varieties, 55 sweet varieties, and 51 accessions with no information, while group II $(\mathrm{N}=247)$ had 50 bitter varieties, 13 sweet varieties, and 184 accessions with no information. The other 88 accessions, which had probabilities lower than $80 \%(\mathrm{Q}<0.80)$ to belong to one of the two groups, were considered admixed individuals, including 14 sweet, 38 bitter, and 26 with no information (Figure 2). At $\mathrm{K}=3, \mathrm{~K}=5$, and $\mathrm{K}=7$, which had $\Delta \mathrm{Ks}$ suggesting some structure, there was no indication that this sub-structure could be attributed to either river basin or types of sweet or bitter varieties within river basins (data not shown).

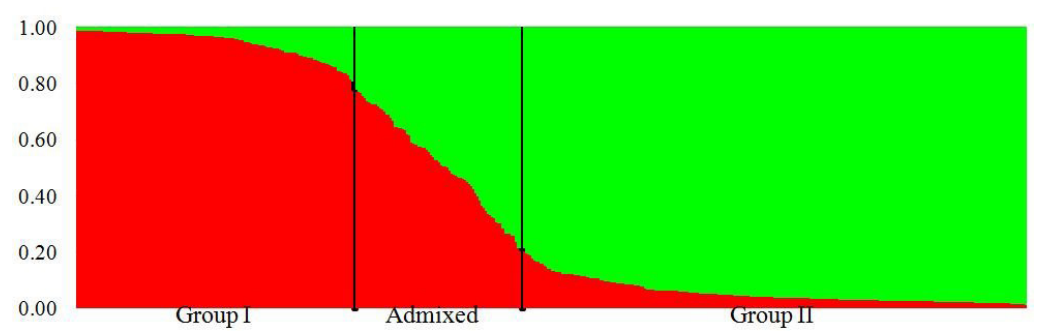

Figure 2. Genetic structure using Bayesian simulation with 470 manioc accessions from the AGB at Embrapa Amazônia Ocidental with $\mathrm{K}=2$ groups, ordered according to the probability value $\mathrm{Q}$.

Genetics and Molecular Research 16 (3): gmr16039690 
In the PCoA with all accessions, the dispersion generally agreed with the groups identified by Structure at $\mathrm{K}=2$ (Figure 3A). However, considering only the 188 accessions discriminated as bitter or sweet varieties, the PCoA was less clear (Figure 3B), although the majority of the sweet varieties were on one side and the majority of the bitter on the other. The accumulated variation in the first two principal coordinates in the two PCoA was small and slightly different, 17.84 and $22.25 \%$, respectively.
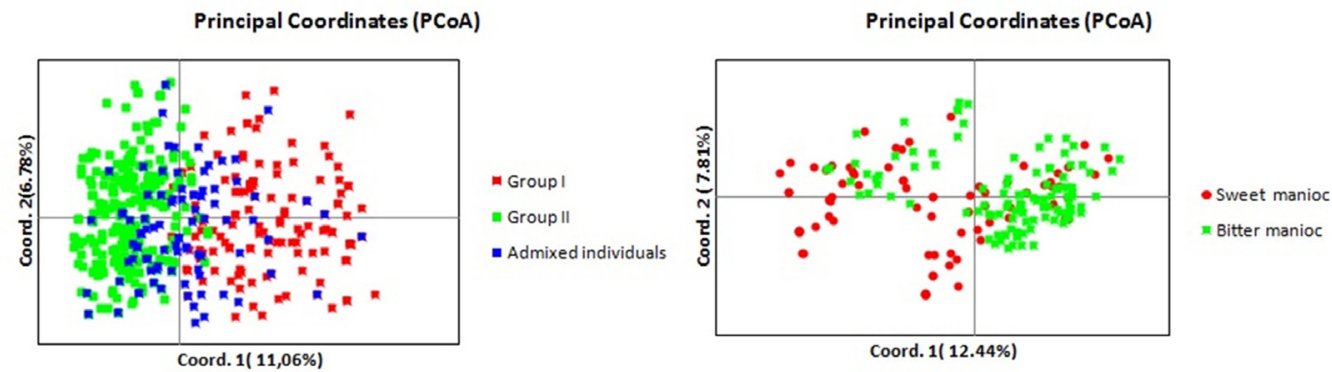

Figure 3. Graphic representation of the dispersion of genetic diversity of 470 AGB manioc accessions using principal coordinate analysis $(\mathrm{PCoA})$ based on 10 SSR loci. A. Accessions according to the groups identified by Structure (red - Group I; green - Group II; blue - admixed individuals). B. Comparison of 188 accessions of sweet (red) and bitter (green) varieties according to their passport information.

The genetic diversity parameters estimated for the groups defined by Structure were similar (Table 2), except for the number of private alleles in Group II (19 alleles). The Shannon diversity index of the three groups ranged from 1.331 to 1.464 . Those estimated for groups of accessions organized by river basins were somewhat less similar, with the lowest mean observed heterozygosity for the Solimões River $(0.51)$ and the highest mean expected heterozygosity for the Negro River (0.71), which also has the highest mean fixation index (0.22). The highest Shannon index (1.514) was found for the Madeira River. The same genetic diversity parameters estimated for the bitter and sweet varieties again yielded similar means between the two groups, with more private alleles (21) and higher fixation index (0.21) for the bitter varieties.

Table 2. Genetic parameters of groups of accessions maintained in the manioc Active Germplasm Bank of Embrapa Amazônia Ocidental grouped by Structure $(K=2$; with admixture defined as $\mathrm{Q}<80 \%)$, river basin, and sweet and bitter varieties.

\begin{tabular}{l|l|c|c|c|c|c|c|c}
\hline Groups & $\mathrm{N}$ & $N_{\mathrm{A}}$ & $\mathrm{Ap}$ & $H_{\mathrm{O}}$ & $H_{\mathrm{E}}$ & $\mathrm{F}$ & $\mathrm{I}$ \\
\hline \multirow{4}{*}{ Structure } & Group I & 135 & 7.2 & 3 & 0.530 & 0.652 & $0.169^{*}$ & 1.331 \\
\cline { 2 - 9 } & Group II & 247 & 10.1 & 19 & 0.553 & 0.643 & $0.116^{*}$ & 1.436 \\
\cline { 2 - 9 } & Admixture & 88 & 8.7 & 6 & 0.550 & 0.663 & $0.185^{*}$ & 1.464 \\
\hline \multirow{5}{*}{ River basin } & Solimões River & 113 & 8.2 & 2 & 0.515 & 0.658 & $0.213^{*}$ & 1.415 \\
\cline { 2 - 9 } & Purus River & 17 & 6.3 & 1 & 0.567 & 0.642 & $0.142^{*}$ & 1.354 \\
\cline { 2 - 9 } & Madeira River & 118 & 9.5 & 6 & 0.578 & 0.688 & $0.160^{*}$ & 1.514 \\
\cline { 2 - 9 } & Negro River & 21 & 6.6 & 1 & 0.550 & 0.709 & $0.239^{*}$ & 1.498 \\
\cline { 2 - 9 } & Amazon River & 113 & 8.3 & 5 & 0.536 & 0.646 & $0.150^{*}$ & 1.414 \\
\cline { 2 - 9 } & Not identified & 88 & 8.7 & 2 & 0.548 & 0.681 & $0.217^{*}$ & 1.505 \\
\hline \multirow{5}{*}{ Varieties } & Sweet manioc & 77 & 7.5 & 7 & 0.545 & 0.648 & $0.147^{*}$ & 1.344 \\
\cline { 2 - 9 } & Bitter manioc & 111 & 8.9 & 21 & 0.538 & 0.671 & $0.209^{*}$ & 1.471 \\
\hline
\end{tabular}

$\mathrm{N}=$ number of accessions; $N_{\mathrm{A}}=$ mean number of different alleles; Ap = private alleles; $H_{\mathrm{O}}=$ mean observed heterozygosity; $H_{\mathrm{E}}=$ mean expected heterozygosity; $\mathrm{F}=$ mean fixation index; $\mathrm{I}=$ mean Shannon index. *Significant at $\mathrm{P}<0.05$.

Genetics and Molecular Research 16 (3): gmr16039690 
AMOVA showed high genetic divergence among groups defined by Structure (without the admixed individuals), much less divergence among the sweet and bitter varieties (defined by passport data), and small divergence among river basins (without the not identified accessions) (Table 3 ).

Table 3. Three hierarchical molecular analyses of variance of accessions in the manioc Active Germplasm Bank at Embrapa Amazônia Ocidental based on the different criteria for defining groups used in Table 2.

\begin{tabular}{l|l|c|c|c|c|c}
\hline Groups & Source of variance & d.f. & SS & MS & $\chi^{2}$ & $\%$ \\
\hline Structure & Between groups & 1 & 304.101 & 304.101 & 1.698 & 18 \\
\hline (K=2, without admixed group) & Within groups & 380 & 2851.982 & 7.505 & 7.505 & 82 \\
\hline River basins & Among rivers & 4 & 117.888 & 29.472 & 0.310 & 4 \\
\hline (without not identified accessions) & Within rivers & 377 & 3011.196 & 7.987 & 7.987 & 96 \\
\hline Varieties & Between varieties & 1 & 53.700 & 53.700 & 0.504 & 6 \\
\hline (sweet and bitter) & Within varieties & 186 & 1471.747 & 7.913 & 7.913 & 94 \\
\hline
\end{tabular}

d.f. $=$ degrees of freedom; $\mathrm{SS}=$ sum of squares; $\mathrm{MS}=$ mean squares; $\chi^{2}=$ variance estimation.

\section{Genetic relationships among accessions}

Using the neighbor-joining algorithm and Nei et al. (1983)'s genetic distance among 470 manioc accessions, we could not identify structuring related to bitter and sweet varieties or to river basins (Figure 4).

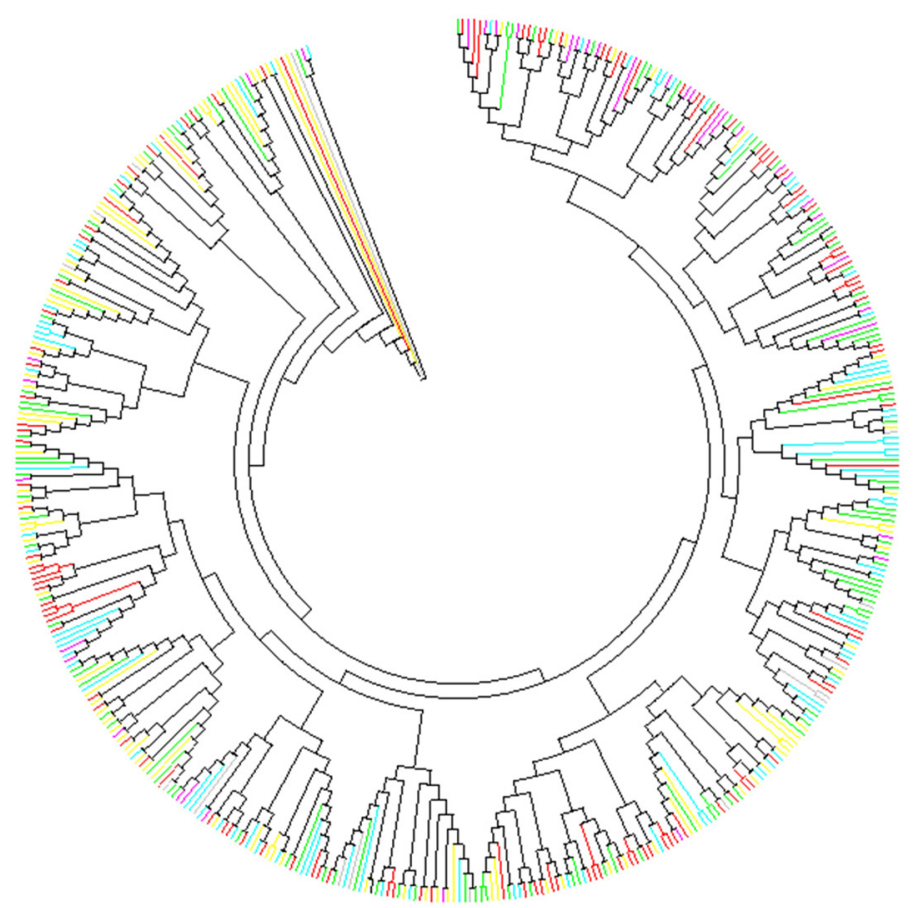

Figure 4. Relationships among 470 manioc accessions in the neighbor-joining dendrogram based on Nei et al. (1983)'s genetic distances estimated with 10 SSR loci. A branch represents an accession and colors represent river channels: Yellow - Amazon River; Green - Solimões River; Red - Madeira River; Pink - Negro River; Gray - Purus River; and blue - not classified to a river.

Genetics and Molecular Research 16 (3): gmr16039690 


\section{DISCUSSION}

Previous genetic studies found high genetic diversity into cultivated M. esculenta in different regions of Brazil (Elias et al., 2004; Peroni et al., 2007; Siqueira et al., 2011; Mühlen et al., 2013). High genetic heterozygosity values have been confirmed even in countries outside of the area of domestication of manioc, such as in Puerto Rico (Montero-Rojas et al., 2011), Uganda (Turyagyenda et al., 2012), and Thailand (Fu et al., 2014). In this study, ample genetic diversity was found among the 470 accessions from the manioc AGB at Embrapa Amazônia Ocidental. Overall, the genetic parameters estimated were closer to those presented by Mühlen et al. (2013), who analyzed 494 varieties from Amazonia and other Brazilian regions, using nine SSR loci, six of which we used. For example, the mean number of alleles per locus in this study was 11.3, while Mühlen et al. (2013) found 9.9 alleles per locus. Likewise, the observed and expected heterozygosities of 0.546 and 0.682 were quite similar to those estimated by Mühlen et al. (2013), who had means of 0.595 and 0.650 , respectively.

These results are consistent with the management of high varietal diversity in traditional farming systems of manioc since manioc is allogamous and produces seedlings that contribute to varietal diversity when farmers select these seedlings for vegetative propagation and planting (Pujol et al., 2005, 2007). In addition, genetic diversity can also be the result of migration that occurs due to variety exchange among neighbors, friends, and relatives, which is very common in the system of traditional agriculture (Pujol et al., 2005; Sardos et al., 2008; Costa et al., 2013).

The simulations by Structure $(\mathrm{K}=2)$ and dendrogram analyses showed no clear correspondence with river basins. The geographic pattern was considered a minor cause of genetic structure in earlier studies on genetic diversity of traditional manioc varieties (Elias et al., 2004; Siqueira et al., 2011). However, Mühlen et al. (2013) identified some geographic structure at $K=3$ and $K=4$, although these were less significant than the $K=2$ sweet-bitter dichotomy, which was also observed by Elias et al. (2004). Based on the pattern of dispersion in PCoA of the groups identified by Structure and of the 188 varieties characterized by the levels of cyanogenic glycosides using available passport data, we found weak sweet-bitter structure, although errors in the passport identification, partial chemical characterization of manioc accessions and mixture during clonal multiplication (on farm and ex situ) may contribute to this. Bradbury et al. (2013) also showed, in African varieties, the occurrence of hybridization, incorrect passport data, and misidentification of sweet or bitter varieties by farmers.

Within varieties, Mühlen et al. (2013) distinguished sweet manioc in the Cerrado from other sweet varieties at $\mathrm{K}=3$ and two groups of bitter varieties, one of which was composed almost exclusively of varieties from the upper Negro River basin, and the other with varieties from all other regions of Brazil at $\mathrm{K}=4$. The small number of accessions from Negro River in our study (20) is certainly the reason why we did not detect something similar, although our sample did not permit an examination of structure outside of the State of Amazonas.

We had expected to find some geographical genetic structure associated with river basins because the exchange of cuttings occurs more between neighboring smallholders than between more distant smallholders (Emperaire and Peroni, 2007; Kawa et al., 2013). However, no such structure was observed, possibly due to lack of geographical barriers in the network of interchange of genetic material among manioc farmers in the Amazon basin. The migration of human populations is one among the possible reasons for closer resemblance among varieties across regions (Siqueira et al., 2011). Moreover, manioc farmers enjoy diversity and eagerly acquire new landraces (Elias et al., 2004).

Genetics and Molecular Research 16 (3): gmr16039690 
Hence, the lack of significant genetic structure in the manioc AGB at Embrapa Western Amazonia can probably be attributed to a combination of factors, including administrative (incomplete and possibly erroneous documentation), genetic (hybridization and incorporation of hybrids), and social factors, especially the extensive exchange of varieties among traditional farmers.

\section{ACKNOWLEDGMENTS}

We thank Embrapa (Brazilian Agricultural Research Corporation - grant \#106010071400), CNPq (National Research Council of Brazil - grant \#407991/2013-1) and FAPEAM (Foundation for the Support of Research in the State of Amazonas - grant \#062.01597/2014) for financial support; FAPEAM also granted a scholarship to S.B. Sousa. Thanks to Alessandro Alves Perreira for help with analyses and to Diniz Carvalho for map making. This study is part of S.B. Sousa Master's thesis in the Graduate Program in Genetics, Conservation and Evolutionary Biology at the National Research Institute for Amazonia.

\section{REFERENCES}

Aiemnaka P, Wongkaew A, Chanthaworn J, Nagashima SK, et al. (2012). Molecular characterization of a spontaneous waxy starch mutation in cassava. Crop Sci. 52: 2121-2130. https://doi.org/10.2135/cropsci2012.01.0058

Alves-Pereira A, Peroni N, Abreu AG, Gribel R, et al. (2011). Genetic structure of traditional varieties of bitter manioc in three soils in Central Amazonia. Genetica 139: 1259-1271. https://doi.org/10.1007/s10709-011-9627-4

Bradbury EJ, Duputié A, Delêtre M, Roullier C, et al. (2013). Geographic differences in patterns of genetic differentiation among bitter and sweet manioc (Manihot esculenta subsp. esculenta; Euphorbiaceae). Am. J. Bot. 100: 857-866. https://doi.org/10.3732/ajb.1200482

Chavarriaga-Aguirre P, Maya MM, Bonierbale MW, Kresovich S, et al. (1998). Microsatellites in cassava (Manihot esculenta Crantz): discovery, inheritance and variability. Theor. Appl. Genet. 97: 493-501. https://doi.org/10.1007/ $\underline{\mathrm{s} 001220050922}$

Costa TR, da Filho PSV, Vidigal MCG, Galván MZ, et al. (2013). Genetic diversity and population structure of sweet cassava using simple sequence repeat (SSR) molecular markers. Afr. J. Biotechnol. 12: 1040-1048.

Doyle JJ and Doyle JL (1987). Isolation of plant DNA from fresh tissue. Focus 1: 13-15.

Duputié A, Massol F, David P, Haxaire C, et al. (2009). Traditional Amerindian cultivators combine directional and ideotypic selection for sustainable management of cassava genetic diversity. J. Evol. Biol. 22: 1317-1325. https://doi. org/10.1111/j.1420-9101.2009.01749.x

Elias M, Mühlen GS, McKey D, Roa, AC, et al. (2004) Genetic diversity of traditional South American landraces of Cassava (Manihot esculenta Crantz): An analysis using microsatellites. Econ. Bot. 58: 242-256.

Emperaire L and Peroni N (2007). Traditional management of agrobiodiversity in Brazil: A case study of manioc. Hum. Ecol. 35: 761-768. https://doi.org/10.1007/s10745-007-9121-x

Evanno G, Regnaut S and Goudet J (2005). Detecting the number of clusters of individuals using the software STRUCTURE: a simulation study. Mol. Ecol. 14: 2611-2620. https://doi.org/10.1111/j.1365-294X.2005.02553.x

Excoffier L and Lischer HEL (2010). Arlequin suite ver 3.5: a new series of programs to perform population genetics analyses under Linux and Windows. Mol. Ecol. Resour. 10: 564-567. https://doi.org/10.1111/j.1755-0998.2010.02847.x

Excoffier L, Smouse PE and Quattro JM (1992). Analysis of molecular variance inferred from metric distances among DNA haplotypes: application to human mitochondrial DNA restriction data. Genetics 131: 479-491.

FAO (Food and Agriculture Organization of the United Nations) (2012). Second report on the state of the world's plant genetic resources for food and agriculture. FAO, Rome.

FAOSTAT (Food and Agriculture Organization of the United Nations Statistics Division) (2014). Available at: [http:// faostat.fao.org]. Accessed May 16, 2016.

Ferguson ME, Jones RB, Bramel PJ, Domínguez C, et al. (2012). Post-flooding disaster crop diversity recovery: a case study of Cowpea in Mozambique. Disasters 36: 83-100. https://doi.org/10.1111/j.1467-7717.2011.01242.x

IBGE - Instituto Brasileiro de Geografia e Estatística (2015). Available at [http://www.ibge.gov.br/home/estatistica/ indicadores/agropecuaria/lspa/default.shtm]. Accessed April 16, 2015.

Fu YB, Wangsomnuk PP and Ruttawat B (2014). Thai elite cassava genetic diversity was fortuitously conserved through

Genetics and Molecular Research 16 (3): gmr16039690 
farming with different sets of varieties. Conserv. Genet. 15: 1463-1478. https://doi.org/10.1007/s10592-014-0631-y Kalia RK, Rai MK, Kalia S, Singh R, et al. (2011). Microsatellite markers: An overview of the recent progress in plants. Euphytica 177: 309-334. https://doi.org/10.1007/s10681-010-0286-9

Kalinowski ST, Taper ML and Marshall TC (2007). Revising how the computer program CERVUS accommodates genotyping error increases success in paternity assignment. Mol. Ecol. 16: 1099-1106. https://doi.org/10.1111/j.1365$\underline{294 X .2007 .03089 . \mathrm{x}}$

Kawa NC, McCarty C and Clement CR (2013). Manioc varietal diversity, social networks, and distribution constraints in rural Amazonia. Curr. Anthropol. 54: 764-770. https://doi.org/10.1086/673528

Langella O (1999). Populations, 1.2.32. Available at [http://bioinformatics.org/ tryphon/populations]. Accessed April, 2015.

Lebot V (2009). Tropical roots and tuber crops: Cassava, sweet potato, yams and aroids. CABI, Oxford.

Mba R, Stephenson P, Edwards K, Melzer S, et al. (2001). Simple sequence repeat (SSR) markers survey of the cassava (Manihot esculenta Crantz) genome: towards an SSR-based molecular genetic map of cassava. Theor. Appl. Genet. 102: 21-31. https://doi.org/10.1007/s001220051614

McKey D, Cavagnaro TR, Cliff J and Gleadow R (2010). Chemical ecology in coupled human and natural systems: people, manioc, multitrophic interactions and global change. Chemoecology 20: 109-133. https://doi.org/10.1007/ s00049-010-0047-1

Montero-Rojas M, Correa AM and Siritunga D (2011). Molecular differentiation and diversity of cassava (Manihot esculenta) taken from 162 locations across Puerto Rico and assessed with microsatellite markers. AoB Plants 2011: plr010. https://doi.org/10.1093/aobpla/plr010

Mühlen GS, Pereira AA, Clement CR and Valle TL (2013). Genetic diversity and differentiation of Brazilian bitter and sweet manioc varieties (Manihot esculenta Crantz, Euphorbiaceae) based on SSR molecular markers. Tipití. J. Soc. Anthropol. Lowland South America 11: 66-73.

Nei M (1987). Molecular evolutionary genetics. Columbia University Press, New York.

Nei M, Tajima F and Tateno Y (1983). Accuracy of estimated phylogenetic trees from molecular data. II. Gene frequency data. J. Mol. Evol. 19: 153-170. https://doi.org/10.1007/BF02300753

Paiva CL (2013). Descritores morfológicos e marcadores microssatélites na caracterização de germoplasma de Passiflora spp. Master's thesis, UNEF, Campos dos Goytacazes.

Oliveira-Silva AM, Silva GF, Dias MC, Clement CR, et al. (2014). Inter-retrotransposon-amplified polymorphism markers for germplasm characterization in Manihot esculenta (Euphorbiaceae). Genet. Mol. Res. 13: 3800-3804. https://doi. org/10.4238/2014.May. 16.3

Olsen K and Schaal B (2001). Microsatellite variation in cassava (Manihot esculenta, Euphorbiaceae) and its wild relatives: further evidence for a southern Amazonian origin of domestication. Am. J. Bot. 88: 131-142. https://doi. org/10.2307/2657133

Peakall R and Smouse PE (2012). GenAlEx 6.5: genetic analysis in Excel. Population genetic software for teaching and research - an update. Bioinformatics 28: 2537-2539. https://doi.org/10.1093/bioinformatics/bts460

Peroni N, Kageyama P and Begossi A (2007). Molecular differentiation, diversity, and folk classification of "sweet" and "bitter" Cassava (Manihot esculenta) in Caiçara and Caboclo management systems (Brazil). Genet. Resour. Crop Evol. 54: 1333-1349. https://doi.org/10.1007/s10722-006-9116-2

Pritchard JK, Stephens M and Donnelly P (2000). Inference of population structure using multilocus genotype data. Genetics 155: 945-959.

Pujol B, Gigot G, Laurent G, Pinheiro-Kluppel M, et al. (2005). Germination ecology of cassava (Manihot esculenta Crantz, Euphorbiaceae) in traditional agroecosystems: seed and seedling biology of a vegetatively propagated domesticated plant. Econ. Bot. 56: 366-379. https://doi.org/10.1663/0013-0001(2002)056[0366:GEOCME]2.0.CO;2

Pujol B, Renoux F, Elias M, Rival L, et al. (2007). The unappreciated ecology of landrace populations: Conservation consequences of soil seed banks in Cassava. Biol. Conserv. 136: 541-551. https://doi.org/10.1016/j.biocon.2006.12.025

Sardos J, McKey D, Duval MF, Malapa R, et al. (2008). Evolution of cassava (Manihot esculenta Crantz) after recent introduction into a South Pacific Island system: the contribution of sex to the diversification of a clonally propagated crop. Genome 51: 912-921. https://doi.org/10.1139/G08-080

Schaal BA, Olsen KM and Carvalho LJCB (2006). Evolution, domestication, and agrobiodiversity in the tropical crop cassava. In: New approaches to the origins, evolution, and conservation of cross (Motley TJ, Zerega N and Hugs H, eds.). Darwin's Harvest, Columbia University Press, New York, 269-284.

Siqueira MVBM, Borges A, Valle TL and Veasey EA (2011). A comparative genetic diversity assessment of industrial and household Brazilian cassava varieties using SSR markers. Bragantia 70: 745-752. https://doi.org/10.1590/S0006$\underline{87052011000400003}$

Genetics and Molecular Research 16 (3): gmr16039690 
Sousa NR, Filho FJN and Souza AGC (2009). Caracterização, avaliação e documentação de recursos genéticos de espécies amazônicas. In: Domesticação e Melhoramento: espécies amazônicas (Borém A, Lopes MTG and Clement CR, eds.). Embrapa, Viçosa, 89-99.

Tamura K, Stecher G, Peterson D, Filipski A, et al. (2013). MEGA6: Molecular Evolutionary Genetics Analysis version 6.0. Mol. Biol. Evol. 30: 2725-2729. https://doi.org/10.1093/molbev/mst197

Turyagyenda LF, Kizito EB, Ferguson ME, Baguma Y, et al. (2012). Genetic diversity among farmer-preferred cassava landraces in Uganda. Afr. Crop Sci. J. 20: 15-30.

Genetics and Molecular Research 16 (3): gmr16039690 